\title{
Chemical Composition of the Essential Oils of Salvia officinalis, S. fruticosa, Melissa officinalis, and their Infusions
}

\author{
Maria Couladis* · Aikaterini Koutsaviti \\ Department of Pharmacognosy and Chemistry of Natural Products, Faculty of Pharmacy, National and Kapodistrian University of Athens, \\ Panepistimiopolis Zografou, Athens 15771, Greece
}

\begin{abstract}
Summary: Dried leaves of commercially available Salvia officinalis, Salvia fruticosa, and Melissa officinalis were divided into two parts; the first part was subjected to hydrodistillation and the second part was used for the preparation of the infusions. The essential oil and the infusion of each sample were subjected to analysis by means of GC-FID and GCMS. The oxygenated monoterpenes 1,8-cineole $(27.5 \%)$ and camphor $(11.5 \%)$ appeared as the most important metabolites in Salvia officinalis, $a$ - and $\beta$-thujone $(16.5 \%, 16.4 \%)$, followed by 1,8 -cineole $(8.8 \%)$ were characterizing the essential oil of Salvia fruticosa, whereas in the oil of Melissa officinalis the sesquiterpene caryophyllene oxide (14.9\%) was the most abundant constituent, followed by geranial $(12.2 \%)$, neral $(11.2 \%)$ and citronellal $(6.7 \%)$. The infusions were characterized by the higher levels of the most important compounds found in the essential oil of the respective sample, as in the case of $S$. officinalis (1,8-cineol 53.6\%, camphor 25.8\%) and $S$. fruticosa ( $a$ - thujone $61.2 \%$, $\beta$-thujone $24.3 \%, 1,8$-cineole $14.5 \%)$, while the infusion of $M$. officinalis was dominated by palmitic and stearic acid $(25.5 \%, 19.5 \%)$.

Key words: chemical composition, essential oils, infusions, Melissa officinalis, Salvia fructicosa, Salvia officinalis
\end{abstract}

\section{Introduction}

Many herbs with potentially beneficial effects which are attributed to their volatile constituents are used as herbal teas. The genus Salvia is one of the largest members of the family Lamiaceae (subfamily Nepetoideae), comprising more than 500 species (Hedge, 1972). In the European flora the genus is represented by 36 species (Hedge, 1972). Members of the genus Salvia have been shown to possess a significant spectrum of pharmacological properties (Newall et al. 1996; Weiss, 1998).

Melissa L. on the other hand, is a small genus, represented in Europe by Melissa officinalis L. (Fernandez, 1972). Lemon balm, M. officinalis, is a perennial herb, cultivated for lemon-scented leaves used as seasoning and in medicine (Mabberley, 1997). In folk medicine this aromatic plant is used against colds and in functional disorders of the circulation. In the Commission $\mathrm{E}$ monographs its use is recorded for nervous sleeping disorders and functional gastrointestinal complaints (Blumenthal, 2000).

The origin however of commercially available medicinal plant material is an important topic for debate

Corresponding author: kouladi@pharm.uoa.gr since many pharmacies, along with various herbal stores provide raw material as plant drugs without certification and accurate botanical identification. Against this background, aim of the present study was the comparison of the essential oil of commercially available Common sage (Salvia officinalis), Greek sage (Salvia fruticosa), and Lemon balm (Melissa officinalis) to the literature data. Additionally, the volatile compounds of the infusions of these taxa was investigated, and compared to the chemical analysis of the respective essential oils.

\section{Materials and Methods}

\section{Plant material}

Plant material included commercially available dried leaves of Salvia officinalis (SOF) and S. fruticosa (SFR), of Albanian and Greek (N. Pindos Mt., Metsovo) origin respectively and dried leaves of Melissa officinalis (M2) originating also from Greece (Crete). The analyzed plant material was purchased from various pharmacies in Athens.

\section{Isolation of the essential oils}

The plant material was subjected to hydrodistillation for $3 \mathrm{~h}$ using a modified Clevenger apparatus to obtain the essential oil. The essential oils were dried over anhydrous sodium sulfate and kept at $4^{\circ} \mathrm{C}$ until analysis. 


\section{Preparation of the infusions}

$2 \mathrm{~g}$ of each sample were added to $60 \mathrm{~mL}$ of boiling distilled water in a stainless steel pot, left at $25^{\circ} \mathrm{C}$ for 15 min and consequently filtered. The filtrate was further subjected to partitioning with $\mathrm{n}$-heptane, and the organic layer was subject to chromatographic analysis by means of GC-FID and GC-MS.

\section{GC-FID \& GC-MS}

GC-MS analysis was carried out using a Hewlett Packard 5973-6890 GC-MS system operating in the EI mode at $70 \mathrm{eV}$, equipped with a HP-5 MS capillary column $(30 \mathrm{~m} \times 0.25 \mathrm{~mm}$; film thickness $0.25 \mu \mathrm{m})$. The initial temperature of the column was $60^{\circ} \mathrm{C}$ and was heated to $280^{\circ} \mathrm{C}$ with a $3^{\circ} \mathrm{C} / \mathrm{min}$ rate (carrier gas $\mathrm{He}$, flow rate $2 \mathrm{ml} / \mathrm{min}$ ).

\section{Identification of components}

The identification of the chemical constituents was based on comparison of their Kováts indices, relative retention times and mass spectra with those reported in the NIST/NBS and Wiley libraries and the literature (Adams, 2007).

\section{Results and Discussion}

\section{Chemical composition of the essential oils}

The chemical composition of the essential oils is presented in Table 1. Oxygenated monoterpenes were the most important class of compounds of all three samples $(45.9 \%-56.1 \%)$.

Oxygen containing monoterpenes 1,8-cineole $(27.5 \%)$ and camphor $(11.5 \%)$ were the most abundant metabolites in $S$. officinalis essential oil, followed by the sesquiterpenes guaiol $(7.7 \%)$ and $(E)$-caryophyllene $(6.9 \%)$. Monoterpene hydrocarbons $a$-pinene and myrcene were also found in considerable amounts $(6.2 \%, 5.0 \%)$.

Salvia fruticosa essential oil on the other hand, was dominated by the presence of cis- and trans-thujone $(16.5 \%, 16.4 \%)$, while 1,8 -cineole $(8.8 \%)$ came third in order, followed by the sesquiterpene hydrocarbons $\delta$ cadinene $(8.1 \%),(E)$-caryophyllene $(6.2 \%)$ and $a$ cubebene $(5.7 \%)$ along with the monoterpene hydrocarbon myrcene $(5.5 \%)$. Worth of notice is the higher abundance of the sesquiterpene fraction in the oil of $S$. fruticosa reaching $37.2 \%$, in comparison to $S$. officinalis essential oil (12.1\%).

According to published data (Pitarokili et al., 2005), $a$-thujone (10-60\%), $\beta$-thujone (4-36\%), camphor (5$20 \%), \quad 1,8$-cineole $(1-15 \%), \quad \beta$-pinene $(0.5-17.9 \%)$, camphene $(1.7-10.3 \%)$, as well as $a$-pinene $(0.9-7.2 \%)$ are typical $S$. officinalis essential oil components. Furthermore, Cvetkovikj et al. (2015), who investigated the chemical diversity of southeast European populations of Dalmatian sage, identified four distinct chemotypes (A-D). Chemotype A was represented by the high content of $\alpha$-thujone and camphor, along with the low levels of $\beta$-thujone, and characterized the majority of the studied material in the aforestated report. Chemotype B on the other hand, was characterized by the high levels of $\alpha$-thujone and $\alpha$ humulene, but camphor was detected only in low amounts. High concentration of both isomers of thujene, along with camphor defined chemotype C, whereas chemotype $\mathrm{D}$ was characterized by the high percentage of camphor and $\beta$-pinene, and by the low abundance of $\alpha$ - and $\beta$-thujone. In addition, Stešević et al. (2014), who studied the chemical variation among twelve populations of indigenous Dalmatian sage in Montenegro, identified the oxygen containing monoterpenes $\alpha$-thujone (16.98-40.35\%), camphor (12.75-35.37\%), 1,8-cineole $(6.40-12.06 \%)$, and $\beta$ thujone $(1.50-10.35 \%)$, as well as the monoterpene hydrocarbon, camphene (2.26-9.97\%), as the most abundant essential oil components of $S$. officinalis.

Hence, it is clear that the commercial sample of Albanian origin, declared as $S$. officinalis, and investigated in our study does not comply with either of the aforementioned chemotypes of Dalmatian sage, since both isomers of thujone are found in significantly lower amounts than expected, whereas the content in 1,8cineole is strikingly higher. However, Miguel et al. (2011), who evaluated the effect of hydrodistillation time on Dalmatian sage essential oil composition of commercially available samples as well, identified also 1,8-cineole (64.3-67.1\%) as the most dominant metabolite, followed by $\alpha$-pinene $(6.5-8.2 \%)$ and camphor (5.3-6.1\%), while $\alpha$-thujone (1.2-1.4\%) and $\beta$ thujone (2.3-2.8\%) were detected only in low amounts too, compared to our analysis. In our analysis the abundance of 1,8-cineole was also remarkably high $(27.5 \%)$, and $\alpha$-pinene, the second most abundant metabolite in the sample of Miguel et al. possessed also a considerable amount (6.2\%). According to Asllani (2000), who investigated the variation of the chemical composition of wild grown $S$. officinalis essential oil from Albania, the abundance of these compounds can vary depending on time of harvest, and collection site. Variations in the chemical profile of $S$. officinalis are also attributed to genetic factors (Bazina et al. 2002; Bazina et al. 2015). Moreover, according to Asllani (2000), the levels of 1,8-cineole and camphor seem to be inversely related to the content of both $a$ - and $\beta$-thujone.

According to the literature data, $a$ - and $\beta$-thujone, most abundant compounds of our sample, were generally found in lower amounts in cultivated $S$. fruticosa, which points to the fact that the chemical profile of cultivated plants also deviate (Pitarokoili et al. 2005). Furthermore, 1,8-cineole, and camphor, are usually identified as the main constituents of $S$. fruticosa essential oil (Bazina et al. 2002, Länger et al. 1996, Bellomaria et al. 1992). However, according to Papageorgiou et al. 2008, who investigated the seasonal variation of chemical composition of $S$. fruticosa collected in Greece, 1,8-cineole (46.0-58.9\%) was 
dominating in the essential oil composition regardless the time of harvest, while camphor was detected in significantly lower amounts (0.7-5.8\%). Significant variation of our experimental data in comparison to the literature data could be of genetic background.

Despite the fact that the dominant group of metabolites are oxygenated monoterpenes (56.1\%) in the oil of Melissa officinalis, the major compound was the sesquiterpene hydrocarbon (E)-caryophyllene (14.9\%), followed by citral isomers, geranial $(12.2 \%)$ and neral $(11.2 \%)$, and citronellal $(6.7 \%)$. Obtained data were generally in accordance to the literature (Teuscher et al. 2003, Shakeri et al. 2016).

Table 1. Chemical composition of the essential oils

\begin{tabular}{|c|c|c|c|c|c|}
\hline No. & Constituents & RI & SOF & SFR & M2 \\
\hline 1 & (Z)-salvene & 847 & - & 0.2 & - \\
\hline 2 & tricyclene & 921 & 0.3 & - & - \\
\hline 3 & $a$-thujene & 924 & - & 0.6 & - \\
\hline 4 & $a$-pinene & 932 & 6.2 & 1.0 & - \\
\hline 5 & camphene & 946 & 4.2 & 0.8 & - \\
\hline 6 & sabinene & 969 & $\operatorname{tr}$ & 0.5 & - \\
\hline 7 & $\beta$-pinene & 974 & 2.6 & 1.3 & - \\
\hline 8 & 6-methyl-5-heptene & 981 & - & - & 0.4 \\
\hline 9 & myrcene & 988 & 5.0 & 5.5 & - \\
\hline 10 & 2E,4E-heptadienal & 1005 & - & - & 0.4 \\
\hline 11 & $a$-terpinene & 1014 & 0.6 & 0.3 & - \\
\hline 12 & p-cymene & 1020 & $\operatorname{tr}$ & $\operatorname{tr}$ & $\operatorname{tr}$ \\
\hline 13 & limonene & 1024 & - & $\operatorname{tr}$ & 0.5 \\
\hline 14 & 1,8-cineole & 1026 & 27.5 & 8.8 & 0.4 \\
\hline 15 & benzene acetaldehyde & 1036 & - & - & 0.4 \\
\hline 16 & $(E)$ - $\beta$-ocimene & 1044 & - & 0.4 & - \\
\hline 17 & $\gamma$-terpinene & 1054 & 0.6 & $\operatorname{tr}$ & $\operatorname{tr}$ \\
\hline 18 & terpinolene & 1086 & 0.2 & $\operatorname{tr}$ & - \\
\hline 19 & linalool & 1095 & 0.4 & - & - \\
\hline 20 & $a$-thujone & 1101 & 1.1 & 16.5 & - \\
\hline 21 & $c i s$-rose oxide & 1106 & - & - & 1.0 \\
\hline 22 & $\beta$-thujone & 1112 & 1.2 & 16.4 & - \\
\hline 23 & trans-rose oxide & 1126 & - & - & 0.5 \\
\hline 24 & camphor & 1141 & 11.5 & 0.6 & - \\
\hline 25 & neoiso-3-thujanol & 1147 & - & $\operatorname{tr}$ & - \\
\hline 26 & citronellal & 1149 & - & - & 6.7 \\
\hline 27 & iso-menthone & 1159 & - & - & 0.5 \\
\hline 28 & borneol & 1165 & $\operatorname{tr}$ & 0.9 & - \\
\hline 29 & neo-iso-pulegol & 1166 & - & - & 1.7 \\
\hline 30 & menthol & 1167 & - & - & 2.0 \\
\hline 31 & terpinen-4-ol & 1174 & 0.8 & 0.3 & - \\
\hline 32 & $a$-terpineol & 1186 & 4.2 & 0.2 & - \\
\hline 33 & methyl chavicol & 1195 & - & - & 3.1 \\
\hline 34 & citronellol & 1223 & - & - & 1.2 \\
\hline 35 & neral & 1235 & - & - & 11.2 \\
\hline 36 & carvone & 1239 & - & - & 5.6 \\
\hline 37 & geraniol & 1249 & - & - & 0.9 \\
\hline 38 & geranial & 1264 & - & - & 12.2 \\
\hline 39 & trans-anethole & 1282 & - & - & 4.3 \\
\hline 40 & isobornyl acetate & 1283 & 0.7 & 1.1 & - \\
\hline 41 & thymol & 1289 & $\operatorname{tr}$ & $\operatorname{tr}$ & $\operatorname{tr}$ \\
\hline 42 & carvacrol & 1298 & 0.8 & 0.5 & 3.2 \\
\hline 43 & methyl geranate & 1322 & - & - & 0.7 \\
\hline 44 & $a$-cubebene & 1345 & - & 5.7 & - \\
\hline 45 & $a$-terpinyl acetate & 1346 & 0.7 & - & - \\
\hline
\end{tabular}




\begin{tabular}{|c|c|c|c|c|c|}
\hline No. & Constituents & RI & SOF & SFR & M2 \\
\hline 46 & eugenol & 1356 & - & - & - \\
\hline 47 & $a$-ylangene & 1373 & - & 0.3 & - \\
\hline 48 & $a$-copaene & 1375 & $\operatorname{tr}$ & 2.7 & 0.4 \\
\hline 49 & $(E)$ - $\beta$-damascenone & 1383 & - & - & 1.9 \\
\hline 50 & $\beta$-bourbonene & 1387 & - & 0.3 & $\operatorname{tr}$ \\
\hline 51 & (E)-caryophyllene & 1417 & 6.9 & 6.2 & 5.8 \\
\hline 52 & $\beta$-gurjunene & 1431 & $\operatorname{tr}$ & - & - \\
\hline 53 & neryl acetone & 1434 & - & - & 0.7 \\
\hline 54 & a-guaiene & 1437 & - & 0.1 & - \\
\hline 55 & aromadendrene & 1439 & 1.1 & 0.2 & - \\
\hline 56 & myltayl-4(12)-ene & 1445 & 0.1 & - & - \\
\hline 57 & trans-muurola-3,5-diene & 1451 & - & 0.4 & - \\
\hline 58 & $a$-humulene & 1452 & 1.6 & 1.3 & 0.4 \\
\hline 59 & allo-aromadendrene & 1458 & 0.2 & - & - \\
\hline 60 & cis-cadina-1(6),4-diene & 1461 & - & 0.2 & - \\
\hline 61 & trans- cadina-1(6),4-diene & 1475 & - & 0.4 & - \\
\hline 62 & $\gamma$-muurolene & 1478 & 0.2 & 1.5 & - \\
\hline 63 & ar-curcumene & 1479 & - & - & 0.8 \\
\hline 64 & $a$-amorphene & 1483 & - & 0.5 & - \\
\hline 65 & germacrene D & 1484 & - & 0.4 & - \\
\hline 66 & $(E)-\beta$-ionone & 1487 & - & - & 1.4 \\
\hline 67 & $\beta$-selinene & 1489 & - & 0.3 & - \\
\hline 68 & cis- $\beta$-guaiene & 1492 & 0.1 & - & - \\
\hline 69 & trans-muurola-4(14),5-diene & 1493 & - & 0.9 & - \\
\hline 70 & $\gamma$-amorphene & 1495 & - & 3.0 & - \\
\hline 71 & viridiflorene & 1469 & 0.5 & - & - \\
\hline 72 & epizonarene & 1501 & 0.2 & - & - \\
\hline 73 & $\delta$-amorphene & 1511 & - & 0.5 & - \\
\hline 74 & $\gamma$-cadinene & 1513 & 0.2 & 0.5 & $\operatorname{tr}$ \\
\hline 75 & myristicin & 1517 & - & - & 0.3 \\
\hline 76 & $\delta$-cadinene & 1522 & $\operatorname{tr}$ & 8.1 & - \\
\hline 77 & cis-calamenene & 1528 & 0.6 & 0.4 & - \\
\hline 78 & trans-cadina-1,4-diene & 1533 & - & 0.6 & - \\
\hline 79 & selina-3,7(11)-diene & 1545 & - & 1.1 & - \\
\hline 80 & $\beta$-vetiverene & 1554 & 0.4 & - & - \\
\hline 81 & germacrene B & 1559 & - & 1.6 & - \\
\hline 82 & spathulenol & 1577 & - & 0.2 & - \\
\hline 83 & caryophyllene oxide & 1582 & 0.9 & - & 14.9 \\
\hline 84 & guaiol & 1600 & 7.7 & - & - \\
\hline 85 & humulene epoxide II & 1608 & 0.3 & $\operatorname{tr}$ & 0.7 \\
\hline 86 & 1-epi-cubenol & 1627 & - & 0.7 & - \\
\hline 87 & 14-hydroxy-(Z)-caryophyllene & 1666 & 1.2 & - & 1.3 \\
\hline 88 & $\begin{array}{l}\text { (E)-14-hydroxy-9-epi- } \\
\text { caryophyllene }\end{array}$ & 1668 & 0.6 & - & - \\
\hline 89 & hexadecanoic acid & 1959 & - & - & 2.1 \\
\hline 90 & manool & 2056 & 2.7 & - & - \\
\hline & \multicolumn{5}{|l|}{ Grouped identified components } \\
\hline & \multicolumn{2}{|l|}{ monoterpene hydrocarbons } & 19.7 & 10.0 & 0.5 \\
\hline & \multicolumn{2}{|l|}{ oxygenated monoterpenes } & 51.5 & 45.9 & 56.1 \\
\hline & \multicolumn{2}{|l|}{ sesquiterpene hydrocarbons } & 12.1 & 37.2 & 9.3 \\
\hline & \multicolumn{2}{|l|}{ oxygenated sesquiterpenes } & 10.7 & 0.9 & 19.3 \\
\hline & \multicolumn{2}{|l|}{ other compounds } & 2.7 & - & 2.5 \\
\hline & \multicolumn{2}{|l|}{ Total } & 96.7 & 94.0 & 87.7 \\
\hline & \multicolumn{2}{|l|}{ oil yield $\% \mathrm{w} / \mathrm{v}$} & 2.08 & 1.53 & 0.03 \\
\hline
\end{tabular}

Constituents listed in order of elution from an HP-5 MS column.

$\mathrm{RI}$, retention indices on the HP-5 MS column relative to $\mathrm{C}_{9}-\mathrm{C}_{23} n$-alkanes.

Identification based on the following scales: I; retention index, MS, mass spectrum obtained from the libraries of the gas chromatography-mass spectrometry system and from the literature.

tr, trace $(<0.1 \%)$ 
Table 2. Chemical analysis of the infusion volatiles

\begin{tabular}{|c|c|c|c|c|c|}
\hline No. & Constituents & RI & SOF & SFR & M2 \\
\hline 1 & $a$-pinene & 932 & $\operatorname{tr}$ & - & - \\
\hline 2 & camphene & 946 & $\operatorname{tr}$ & - & - \\
\hline 3 & myrcene & 988 & $\operatorname{tr}$ & $\operatorname{tr}$ & - \\
\hline 4 & $p$-cymene & 1020 & $\operatorname{tr}$ & - & - \\
\hline 5 & 1,8-cineole & 1026 & 53.6 & 14.5 & - \\
\hline 6 & linalool & 1095 & $\operatorname{tr}$ & - & - \\
\hline 7 & $a$-thujone & 1101 & 1.1 & 61.2 & - \\
\hline 8 & $\beta$-thujone & 1112 & 1.1 & 24.3 & - \\
\hline 9 & camphor & 1141 & 25.8 & - & - \\
\hline 10 & $\delta$-terpineol & 1162 & 1.4 & - & - \\
\hline 11 & borneol & 1165 & 1.3 & - & - \\
\hline 12 & terpinen-4-ol & 1174 & $\operatorname{tr}$ & - & - \\
\hline 13 & $a$-terpineol & 1186 & 4.6 & - & - \\
\hline 14 & neral & 1235 & - & - & 3.4 \\
\hline 15 & carvone & 1237 & - & - & 4.2 \\
\hline 16 & geranial & 1264 & - & - & 6.3 \\
\hline 17 & carvacrol & 1298 & $\operatorname{tr}$ & $\operatorname{tr}$ & $\operatorname{tr}$ \\
\hline 18 & $a$-cubebene & 1345 & - & $\operatorname{tr}$ & - \\
\hline 19 & hexadecanoic acid/ palmitic acid & 1959 & - & - & 25.5 \\
\hline 20 & octadecanoic acid/stearic acid & 2170 & - & - & 19.5 \\
\hline
\end{tabular}

Constituents listed in order of elution from an HP-5 MS column.

$\mathrm{RI}$, retention indices on the HP-5 MS column relative to $\mathrm{C}_{9}-\mathrm{C}_{23}$ n-alkanes.

Identification based on the following scales: I; retention index, MS, mass spectrum obtained from the libraries of the gas chromatography-mass spectrometry system and from the literature.

tr, trace $(<0.1 \%)$

\section{Chemical composition of the infusions volatiles}

The infusion of $S$. officinalis was richer in 1,8-cineole and camphor $(53.6 \%, 25.8 \%$ respectively) components. In $S$. fruticosa the oxygenated monoterpenes cis- and transthujone $(61.2 \%, 24.3 \%)$ were identified as the main infusion volatiles, followed by 1,8-cineole $(14.5 \%)$.

Palmitic $(25.5 \%)$ and stearic acid $(19.5 \%)$ on the other hand, were the main metabolites of the volatile fraction in the infusion of $M$. officinalis, whereas the main metabolites of the essential oil, geranial $(6.3 \%)$ and neral (3.4\%), appeared in lesser amounts. Carvone, an oxygenated monoterpene, presented in $M$. officinalis essential oil $(5.6 \%)$, was identified in a considerable amount $(4.2 \%)$ also in the infusion volatiles.

\section{Conclusions}

Oxygenated monoterpenes were the dominant group of compounds of commercially available Salvia essential oils; however the chemical analysis showed significant deviation from the literature data. Specifically the chemical profile of the sample of Albanian origin, declared as $S$. officinalis, was similar to the chemical profile of $S$. fruticosa, according to published data. In a similar way, the essential oil analysis of sage of Greek origin, botanically identified as $S$. fruticosa, resembled to the chemical profile of $S$. officinalis.
Noteworthy is the fact that caryophyllene oxide, one of the most abundant metabolite of Melissa officinalis essential oil, was not detected in the analysis of $M$. officinalis infusion volatiles, probably due to hydrolysis during extraction.

The fact that our experimental data, specifically the chemical analyses of the Salvia samples are generally not in accordance to the literature data, indicates an inaccurate botanical identification of the distributed raw material in the market of plant drugs. Hence, we believe that an accurate botanical identification and classification of the distributed plant material would be of great significance and extremely critical in order to ensure safe handling of all plant drugs and to avoid unintentional mishandling of potentially unsafe pharmaceutical plant material.

\section{References}

Adams, R.P. (2007). Identification of essential oil components by gas chromatography/quadrupole mass spectroscopy, 4th ed. Carol Stream, IL: Allured Publishing Corporation.

Asllani, U. (2000). Chemical composition of Albanian Sage oil (Salvia officinalis L.). Journal of Essential Oil Research, 12, 79-84. http:// dx.doi.org/10.1080/10412905.2000.9712048

Bazina, E. (2015). Chemical variation in essential oils of Salvia officinalis L. Ecotypes cultivated in Albania. Journal of Life Sciences, 9, 95102. doi: $10.17265 / 1934-7391 / 2015.03 .002$ 
Bazina, E., Makris. A., Vender, C., Skoula, M. (2002). Genetic and chemical relations among selected clones of Salvia oficinalis. Journal of Herbs, Spices \& Medicinal Plants, 9, 269-273. http:// dx.doi.org/10.1300/J044v09n04_02

Bellomaria, B., Arnold, N., Valentini, G., Arnold, H.J. (1992). Contribution to the study of the essential oils from three species of Salvia growing wild in the eastern Mediterranean region. Journal of Essential Oil Research, 4, 607-614. doi: 10412905/92/0006-0607\$04.00/0

Blumenthal, M., Goldberg. A., Brinckmann. J. (2000). Herbal Medicine, Expanded Commission E Monographs. Austin Texas: American Botanical Council.

Cvetkovikj, I., Stefkov, G., Karapandzova, M., Kulevanova, S., Satović, Z. (2015). Essential Oils and chemical diversity of southeast European populations of Salvia officinalis L. Chemistry and Biodiversity, 12, 1025-1039. doi: 10.1002/cbdv.201400273

Fernandes, R. (1972). Melissa L. In T.G. Tutin, V.H. Heywood, N.A. Burges, D.M. Moore, D.H. Valentie, S.M. Walters, D.A. Webb (Eds.), Flora Europaea Vol. 3 (p. 162). Cambridge: Cambridge University Press.

Hedge, I.C. (1972). Salvia L. In T.G. Tutin, V.H. Heywood, N.A. Burges, D.M. Moore, D.H. Valentie, S.M. Walters, D.A. Webb (Eds.), Flora Europaea, Vol. 3, (p. 188). Cambridge: Cambridge University Press.

Länger, R., Mechtler, C., Jurenitsch, J. (1996). Composition of the essential oils of commercial

samples of Salvia officinalis L. and S. fruticosa Miller: A comparison of oils obtained by extraction and steam distillation. Phytochemical Analysis, 7, 289-293. doi: 10.1002/(SICI)1099-1565(199611) 7:6<289::AID-PCA318>3.0.CO;2-7
Mabberley, D.J. (1997). The Plant Book, $2^{\text {nd }}$ edn. Cambridge: Cambridge University

Miguel, G., Cruz, C., Faleiro M.L., Simões, M.T.F., Figueiredo, A.C., Barroso J.G., Pedro L.G. (2011). Salvia officinalis L. essential oils: effect of hydrodistillation time on the chemical composition, antioxidant and antimicrobial activities. Natural Product Research, 5, 526-541. doi: 10.1080/14786419.2010.499513

Newall, C.A., Anderson, L.A., Phillipson, J.D. (1996). Herbal Medicines: A Guide for Healthcare Professionals. London: Pharmaceutical Press.

Pitarokili, D., Tzakou, O., Couladis M. (2005). Chemical constituents of the Genus Salvia. Hellenic Community of Ethnopharmacology. "Greek Sage".

Stešević, D., Ristić, M., Nikolić, V., Nedović, M., Caković, D., Šatović Z. (2014). Chemotype diversity of indigenous Dalmatian sage (Salvia officinalis L.) populations in Montenegro. Chemistry and Biodiversity, 11, 101-114. doi: 10.1002/cbdv.201300233

Papageorgiou, V., Gardelli, C., Malouchos, A., Papaioannou, M., Komaitis, M. (2008). Variation of the chemical profile and antioxidant behavior of Rosmarinus officinalis L. and Salvia fruticosa Miller grown in Greece. Journal of Agricaltural and Food Chemistry, 56, 7254-7264. doi: 10.1021/jf800802t

Shakeri, A., Sahebkar, A., Javadi, B. (2016). Melissa officinalis L. - A review of its traditional uses, phytochemistry and pharmacology. Journal of Ethnopharmacology, 188, 204-228. http:// dx.doi.org/10.1016/j.jep.2016.05.010

Teuscher, E., Bauermann, U., Werner, M. (2003). Medicinal Spices. A handbook of Culinary Herbs, Spices, Spice mixtures and their Essential oils. Stuttgart.: GmbH Scientific Publishers

Weiss, R.F. (1998). Herbal Medicine. Beaconsfield: Beaconfield Publishers.

\section{Hemijski sastav etarskih ulja Salvia officinalis, S. fruticosa, Melissa officinalis i njihovih infuzuma}

\section{Maria Couladis · Aikaterini Koutsaviti}

Sažetak: U ovom radu ispitivan je sastav isparljivih komponenti komercijalno dostupnih vrsta Salvia officinalis, Salvia fruticosa i Melissa officinalis. Osušeni listovi biljaka razdvojeni su u dve grupe. Prva grupa je podvrgnuta hidrodestilaciji (za dobijanje etarskog ulja), a druga je korišćena za pripremu infuzuma. Hemijski sastav etarskog ulja prve grupe uzoraka $\mathrm{i}$ infuzum druge grupe ispitivan je primenom GC-FID i GC-MS tehnike. U etarskim uljima sva tri uzorka nađene su velike količine oksidovanih monoterpena (51,5\%, 45,9\%, 56,1\%). U etarskom ulju Salvia officinalis su bili dominantni 1,8-cineol (27,5\%) i kamfor (11,5\%), u etarskom ulju Salvia fruticosa $\alpha$ - and $\beta$-tujon $(16,5 \%, 16,4 \%)$ i 1,8cineol (8,8\%), dok je u etarskom ulju Melissa officinalis nađen najveći sadržaj seskviterpena kariofilen-oksida $(14,9 \%)$ i oksidovanih monoterpena, geraniala $(12,2 \%)$, nerala $(11,2 \%)$ i citronelala $(6,7 \%)$. U isparljivim frakcijama infuzuma najzastupljenije su bile iste komponente koje su dominirale i u etarskim uljima ispitivanih vrsta biljaka: $S$. officinalis $(1,8$ -cineol 53.6\% i kamfor 25,8\%) i S. fruticosa ( $\alpha$-tujon 61,2\%, $\beta$-tujon 24,3\%, 1,8-cineol 14,5\%), dok su u infuzumu $M$. officinalis dominantne komponente bile palmitinska (25.5\%) i stearinska kiselina (19,5\%).

Ključne reči: etarska ulja, hemijski sastav, infuzumi, Melissa officinalis, Salvia fructicosa, Salvia officinalis 